\title{
Influence of postpartum energy restriction on energy status, plasma LH and oestradiol secretion and follicular development in suckled beef cows
}

\author{
B. Grimard ${ }^{1,2}$, P. Humblot ${ }^{2}$, A. A. Ponter ${ }^{1}$, J. P. Mialot ${ }^{1}$, D. Sauvant ${ }^{3}$ \\ and M. Thibier ${ }^{2}$ \\ ${ }^{1}$ Ecole Veterinaire d'Alfort, Laboratoire d'épidémiologie et de gestion de la santé animale, 7 av. du Général \\ de Gaulle, 94704 Maisons Alfort Cedex, France; ${ }^{2}$ Union Nationale des Coopératives d'Elevage et \\ d'Insémination Artificielle, 13 rue Jouet, BP 65, 94703 Maisons Alfort Cedex, France; \\ and ${ }^{3}$ Institut National Agronomique Paris-Grignon, Station de Nutrition, 16 rue Claude Bernard, \\ 75231 Paris Cedex 05, France
}

\begin{abstract}
Effects of postpartum energy restriction, parity and time after parturition on energy status (measured by glucose, insulin, non-esterified fatty acids (NEFAs) and $\beta$-hydroxybutyrate), LH secretion and follicular growth were investigated in ten primiparous and nine multiparous suckled cows. Females were allocated by parity, body mass and body condition score at calving to diets supplying either $100 \%(\mathrm{CE}, n=10)$ or $70 \%(\mathrm{LE}, n=9)$ of energy requirements until day 70 postpartum. Metabolic parameters were measured every week from calving to day 70 postpartum. Blood samples were collected at intervals of $15 \mathrm{~min}$ for $10 \mathrm{~h}$ on day 30 and day 50 after parturition for LH measurement. Ovaries were examined between days 20 and 30 and days 40 and 50 postpartum by ultrasonography. Energy supply affected mean plasma concentrations of glucose (CE: $0.64 \pm 0.01 \mathrm{~g} \mathrm{l}^{-1}$ versus LE: $\left.0.61 \pm 0.01 \mathrm{~g} \mathrm{l}^{-1} ; P<0.05\right)$ and NEFA (CE: $168 \pm 17 \mu \mathrm{eq} \mathrm{l^{-1 }}$ versus LE: $309 \pm 18 \mu \mathrm{eq} \mathrm{l}^{-1}$; $p<0.01$ ) but by day 70 postpartum, glucose and NEFA concentrations were not significantly different between the two groups. LH pulse amplitude and frequency were not affected by energy supply $(P>0.10)$. However, at day 30 postpartum, LH pulse frequency was negatively correlated with plasma concentration of NEFA $(r=-0.61 ; P<0.01)$. Cows fed diets supplying $100 \%$ of energy requirements had more large follicles than did cows fed low energy diets (CE: $0.82 \pm 0.05$ versus LE: $0.31 \pm 0.05 ; P<0.05$ ). The size of the largest follicle was greater in CE cows than in LE cows (CE: $10.2 \pm 0.1 \mathrm{~mm}$ versus LE: $8.7 \pm 0.2 \mathrm{~mm}$; $P<0.05$ ). Between 40 and 50 days postpartum, the size of the largest follicle was negatively correlated with NEFA concentration $(r=-0.5 ; P<0.05)$. These results suggest that $\mathrm{LH}$ pulse frequency might be affected by energy supply when energy balance was strongly negative, whereas follicular growth was affected at a later stage, after parturition.
\end{abstract}

\section{Introduction}

It is well established that undernutrition in postpartum beef cows increases the time to onset of ovarian activity and first oestrus (Randel, 1990; Short et al., 1990). However, the precise mechanisms through which nutrition affects reproduction are uncertain. Recovery of ovarian function after calving is preceded by an increase in the frequency and amplitude of pulsatile LH release (Nett, 1987; Short et al., 1990) and resumption of the growth of dominant follicles (Savio et al., 1990; Murphy et al, 1990). Studies on the effects of energy restriction on LH secretion and follicular growth have produced conflicting results. It has been reported that undernutrition decreases (Terqui et al., 1982; Whisnant et al., 1985;

Received 28 October 1994.
Wright et al., 1987; Perry et al., 1991) or has no effect (Rutter and Randel, 1984; Wright et al., 1987; Perry et al., 1991; Wright et al., 1992) on mean basal concentrations of LH, LH pulse frequency or LH pulse amplitude. Prado et al. (1990) reported an effect of body condition score at calving on the number of follicles present 5 weeks postpartum but not 9 weeks postpartum. Perry et al. (1991) reported that follicular growth was affected by undernutrition only in cows with a low body condition score at calving. Therefore, individual energy status could be a more important factor than the energy level of the diet in determining the effects of nutrition on reproduction. In the few studies in beef cows, circulating glucose, insulin, non-esterified fatty acids, ketone bodies (mainly $\beta$ hydroxybutyrate) and urea were used to estimate energy status (Russel and Wright, 1983; Easdon et al., 1985) and there is little information on reproductive events. The aims of this study 
were: (I) to measure changes in individual energy status in restricted postpartum beef cows by monitoring blood parameters reflecting intermediary metabolism; (2) to evaluate whether there are differences in LH secretion or in ovarian function (follicular characteristics and oestradiol secretion) in restricted cows and whether they are associated with differences in circulating concentrations of metabolic hormones or blood metabolites; and (3) to study possible interactions between these processes and parity.

\section{Materials and Methods}

\section{Animals and diets}

Nineteen Charolais cows (ten primiparous and nine multiparous), calving between December 1992 and February 1993, were studied. Animals were kept in stalls and calves were allowed to suckle their mothers twice a day.

After parturition, cows were allotted by parity, body condition score and body mass at calving and offered $100 \%$ (Control Energy diet, CE, $n=10$ ) or $70 \%$ (Low Energy diet, LE, $n=9$ ) of energy requirements and $100 \%$ and $75 \%$ of the protein requirements calculated according to Petit (1988) until day 70 postpartum. Digestible energy for control multiparous and primiparous cows were, respectively, $26.5 \mathrm{Mcal}$ (i.e. $14 \mathrm{Mcal}$ net energy) and $25 \mathrm{Mcal}$ (i.e. $13.6 \mathrm{Mcal}$ net energy). Total crude protein for control multiparous and primiparous cows was $1100 \mathrm{~g}$ (i.e., $760 \mathrm{~g}$ intestinal digestible protein) and $1030 \mathrm{~g}$ (i.e., $740 \mathrm{~g}$ intestinal digestible protein), respectively. Diets provided $100 \%$ of mineral and vitamin needs in the two groups and comprised natural prairie hay, soya bean meal and sugar beet pulp.

Dams were weighed and scored for body condition (scale from 1 to 5, Agabriel et al., 1986) every 20 days from calving to day 60 postpartum. Ease of calving was scored from 1 (no assistance at calving) to 4 (Caesarean delivery). Calves were weighed at birth and at day 60 postpartum.

\section{Blood samples}

Blood samples were collected by caudal venepuncture every week, from calving until day 70 postpartum, into heparinized tubes before morning feeding, and assayed for blood metabolites and progesterone. On days 30 and 50 after parturition, cows were fitted with a jugular catheter and blood samples were collected every $15 \mathrm{~min}$ for $10 \mathrm{~h}$ for analysis of $\mathrm{LH}$ pulsatility. Plasma was stored at $-18^{\circ} \mathrm{C}$ after centrifugation (at $2500 \mathrm{~g}$ for $20 \mathrm{~min}$ ) until required for analysis.

\section{Assays}

Blood metabolites and insulin. Weekly blood samples were analysed by photometric methods for glucose (PM 7546860 Dart Glucose; Coulter Diagnostics, Hialeah), non-esterified fatty acids (NEFA C 46551; Wako Chemicals, Neuss), $\beta$-hydroxybutyrate (method adapted from Barnouin et al., 1986) and urea (PN 7507638G, Dart Urée; Coulter Diagnostics, Hisleah). Intra- and interassay coefficients of variation were
0.6 and $0.8 \%$ between 0.2 and $1.2 \mathrm{~g} \mathrm{l}^{-1}$ for the glucose assay, 4.5 and $0.3 \%$ between 20 to $1000 \mu$ eq $\mathrm{l}^{-1}$ for NEFA, 3.7 and $1 \%$ between 20 to $600 \mathrm{mg} \mathrm{l}^{-1}$ for $\beta$-hydroxybutyrate, 1.7 and $5.6 \%$ between 0.05 and $1.7 \mathrm{~g} \mathrm{l}^{-1}$ for urea assay, respectively. Insulin concentrations were measured by radioimmunoassay (RIA Kits, INSI-PR, CIS Bio International, Gif sur Yvette). Human insulin in serum was used as standard $(0-500 \mu \mathrm{iu}$ $\left.\mathrm{ml}^{-1}\right)$. The antiserum, raised in guinea-pigs, displayed $100 \%$ crossreactivity with bovine insulin. Intra- and interassay coefficients of variation were 9 and $8.7 \%$, respectively, and the assay sensitivity was $3 \mu \mathrm{iu} \mathrm{ml} \mathrm{u}^{-1}$.

Reproductive hormones. LH was assayed by enzyme immunoassay (Sanofi Santé Animale, Libourne; Maurel, 1991). As reported by Maurel (1991), crossreactivity with bovine LH and the correlation with the specific radioimmunoassay were excellent ( $>95 \%$ ). As established by Boly et al. (1994), sensitivity of the assay was less than $0.1 \mathrm{ng} \mathrm{ml}^{-1}$, and the intra- and interassay coefficients of variation were 3 and $10 \%$, respectively. LH peaks were defined by an iterative process as groups of values higher than basal values plus $2 \mathrm{SD}$. Basal concentrations were calculated by averaging the LH concentrations without peak values. The amplitude of an $\mathrm{LH}$ pulse was the difference between the greatest concentration of this peak and mean basal LH concentration.

Oestradiol was assayed from single aliquots $(1 \mathrm{ml})$ of plasma in five samples taken every hour during the frequent sampling period. After extraction with $4 \mathrm{ml}$ ether (Prolabo, Paris), the radioimmunoassay was performed with a specific polyclonal antibody (Ref. 2054-S4; FRH, Fresnes), displaying less than 5\% crossreactivity with major oestrogens likely to interfere in the assay (oestrone $4 \%$ and oestriol $2.5 \%$ ). This antibody was used at a final dilution of 1:30 000. Blank ether was usually found to equal 0 and was always lower than $2 \mathrm{pg}$. It was subtracted systematically from individual plasma concentrations. Intraand interassay coefficients of variation were 6.7 and $8.8 \%$, respectively, and the minimum sensitivity of the assay was $2 \mathrm{pg} \mathrm{ml}^{-1}$.

The concentrations of progesterone in plasma were measured by radioimmunoassay (Thibier and Saumande, 1975, as modified by Humblot et al., 1990). Intra- and interassay coefficients of variation were 2 and $8 \%$, respectively. The sensitivity of the assay was $50 \mathrm{pg} \mathrm{ml}{ }^{-1}$. A concentration higher than $1.5 \mathrm{ng} \mathrm{ml}^{-1}$ was considered to indicate the presence of a functional corpus luteum.

\section{Follicular characteristics}

The ovaries were examined every 2 days by transrectal ultrasonography (PIE DATA; $5 \mathrm{Mhz}$ transducer; Pierson and Ginther, 1984) between 20 and 30 days (period 1), and 40 and 50 days (period 2) after calving. The minimum diameter of the detected follicles was $3 \mathrm{~mm}$. Follicles were assigned to three diameter classes: small $(<5 \mathrm{~mm})$; medium $(\geq 5-$ $<10 \mathrm{~mm})$; and large $(\geq 10 \mathrm{~mm})$. A dominant follicle was defined as a follicle larger than $10 \mathrm{~mm}$ diameter present in the ovary in the absence of other large follicles (Murphy et al., 1990). 


\section{Statistical analyses}

Effects of energy supply, parity, time postpartum and corresponding interactions on blood concentrations of glucose, NEFAs, $\beta$-hydroxybutyrate, urea and insulin were tested by split-plot ANOVA, after logarithmic transformation when necessary (SAS, 1987). A similar model was used to test these effects on LH secretion (mean basal value, number of LH peaks per $10 \mathrm{~h}$ and amplitude of the LH peaks), oestradiol secretion (mean concentration calculated from the five samples taken every hour during the two periods) and follicular characteristics (mean number of follicles by class, size of the largest follicle and percentage of cows bearing a dominant follicle during a given period). Scheffe's test was used when making post split-plot ANOVA multiple comparisons.

Pearson correlation coefficients were calculated between mean concentrations of blood metabolites and insulin 2, 3 and 4 weeks after calving, and blood hormones and follicular characteristics during period 1 (20-30 days postpartum); and then between mean concentrations of blood metabolites and insulin 5, 6 and 7 weeks after calving, and blood hormone and follicular characteristics during period 2 (40-50 days postpartum).

All results are presented as means \pm SEM.

\section{Results}

\section{Energy status variations}

Body mass at calving, body condition score at calving and ease of calving were not significantly different in the two groups $(583 \pm 17 \mathrm{~kg}, 2.15 \pm 0.13$ and $2.3 \pm 0.4$, respectively, for the CE cows and $593 \pm 17 \mathrm{~kg}, 2.38 \pm 0.13$ and $2.4 \pm 0.4$, respectively, for the LE cows). Body mass and body condition score variations were different in the two groups. Cows fed a low energy diet lost $31.0 \pm 6.1 \mathrm{~kg}$ and $0.44 \pm 0.17$ body condition points, whereas these variables were unchanged in control cows $(+0.15 \pm 0.7 \mathrm{~kg}$ body mass; $P<0.001$ and $+0.05 \pm 0.08$ body condition points; $P<0.05$ ). The daily gain in body mass of the calves was lower in the LE group than in the $C E$ group $(595 \pm 39 \mathrm{~g}$ versus $785 \pm 40 \mathrm{~g} ; P<0.01)$.

Mean plasma concentrations of glucose and urea from calving to day 70 postpartum were higher in $\mathrm{CE}$ cows than in $\mathrm{LE}$ ones $\left(0.64 \pm 0.01 \mathrm{~g} \mathrm{l}^{-1}\right.$ versus $0.61 \pm 0.01 \mathrm{~g}^{-1} ; P<0.05$ and $0.22 \pm 0.01 \mathrm{~g} \mathrm{I}^{-1}$ versus $\left.0.17 \pm 0.01 \mathrm{~g} \mathrm{l}^{-1} ; P<0.01\right)$. In $\mathrm{CE}$ cows, plasma concentrations of insulin tended to be higher $\left(5.11 \pm 0.35 \mu \mathrm{iu} \mathrm{ml}{ }^{-1}\right.$ versus $3.48 \pm 0.37 \mu \mathrm{iu} \mathrm{ml}{ }^{-1} ; P=0.08$ ) than in LE cows. Glucose and insulin concentrations increased in primiparous cows when energy supply increased from 70 to $100 \% \quad\left(0.60 \pm 0.01 \mathrm{~g} \mathrm{I}^{-1}\right.$ to $0.69 \pm 0.01 \mathrm{~g}^{-1}$ and $2.57 \pm 0.49 \mu \mathrm{iu} \mathrm{ml}{ }^{-1}$ to $6.78 \pm 0.49 \mu \mathrm{iu} \mathrm{ml} \mathrm{ml}^{-1}$, respectively). However, there were no significant differences between the two energy levels in multiparous cows (glucose: $0.62 \pm 0.01 \mathrm{~g}$ $\mathrm{l}^{-1}$ to $0.61 \pm 0.01 \mathrm{~g} \mathrm{l}^{-1}$; and insulin: $4.39 \pm 0.55 \mu \mathrm{iu} \mathrm{ml} l^{-1}$ to $3.45 \pm 0.49 \mu \mathrm{iu} \mathrm{ml}{ }^{-1}$; interaction energy supply $\times$ parity, $P<0.01$ ). Mean plasma concentrations of NEFAs were lower in $C E$ than in LE cows $\left(168 \pm 17 \mu \mathrm{eq} \mathrm{l}^{-1}\right.$ versus $\left.309 \pm 18 \mu \mathrm{eq} \mathrm{l}^{-1} ; \quad P<0.01\right)$. There was no effect of dietary energy level on mean plasma $\beta$-hydroxybutyrate concentrations $\left(28.0 \pm 0.7 \mathrm{mg} \mathrm{l}^{-1}\right.$ in $C E$ cows versus $25.0 \pm 0.7 \mathrm{mg} \mathrm{l}^{-1}$ in LE cows; $P>0.05$ ).

Plasma concentrations of glucose and insulin decreased with time postpartum $(P<0.01$ and 0.05 , respectively; Fig. I) when mean plasma NEFA concentrations tended to decrease $(P=0.13)$ and blood concentrations of urea increased $(P<0.05)$. Time had no significant effect on plasma concentrations of $\beta$-hydroxybutyrate. Seven weeks after calving, glucose, insulin and NEFA concentrations were not significantly different between the CE and LE cows $\left(0.61 \pm 0.01 \mathrm{~g} \mathrm{l}^{-1}\right.$ versus $0.58 \pm 0.02 \mathrm{~g} \mathrm{l}^{-1} ; 3.24 \pm 0.47 \mu \mathrm{iu} \mathrm{ml} l^{-1}$ versus $3.20 \mu \mathrm{iu}$ $\mathrm{ml}^{-1} ; 161 \pm 28 \mu \mathrm{eq} \mathrm{I}^{-1}$ versus $170 \pm 42 \mu \mathrm{eq} \mathrm{l^{-1 }}$; Fig. 1).

A positive correlation was found between plasma glucose and insulin concentrations during period $1(r=0.67 ; P<0.01$; $n=19)$ but not period $2(r=0.45 ; P=0.06 ; n=19)$.

\section{Reproductive hormones}

LH. Between day 30 and day 50 postpartum, mean basal LH concentrations and the amplitude of the LH peaks did not significantly vary $\left(0.20 \pm 0.01 \mathrm{ng} \mathrm{ml}^{-1}\right.$ versus $0.32 \pm 0.09 \mathrm{ng}$ $\mathrm{ml}^{-1}, P>0.05 ; 1.02 \pm 0.21 \mathrm{ng} \mathrm{ml}^{-1}$ versus $0.85 \pm 0.22 \mathrm{ng}$ $\left.\mathrm{ml}^{-1}, P>0.05\right)$ but the number of LH peaks per $10 \mathrm{~h}$ increased ( $1.77 \pm 0.30$ versus $2.59 \pm 0.29, P<0.05$ ).

For primiparous cows, mean basal concentrations of $\mathrm{LH}$, and the amplitude and frequency of LH pulses were lower than for multiparous cows $\left(0.20 \pm 0.06 \mathrm{ng} \mathrm{ml}^{-1}\right.$ versus $0.39 \pm 0.08 \mathrm{ng}$ $\mathrm{ml}^{-1}, P=0.05 ; 0.55 \pm 0.18 \mathrm{ng} \mathrm{ml}^{-1}$ versus $1.31 \pm 0.23 \mathrm{ng}$ $\mathrm{ml}^{-1}, P<0.01 ; 1.75 \pm 0.27$ per $10 \mathrm{~h}$ versus $2.61 \pm 0.32$ per $10 \mathrm{~h}, P<0.05)$.

Energy supply had no significant effect on mean basal concentrations of LH (CE: $0.21 \pm 0.23 \mathrm{ng} \mathrm{ml}^{-1}$ versus LE: $0.38 \pm 0.08 \mathrm{ng} \mathrm{ml}^{-1} ; P>0.05$ ), the number of LH peaks per $10 \mathrm{~h}$ (CE: $2.25 \pm 0.23$; LE: $2.00 \pm 0.42 ; P>0.05$ ) and the amplitude of LH peaks (CE: $0.81 \pm 0.20 \mathrm{ng} \mathrm{ml}^{-1}$; LE: $\left.1.05 \pm 0.23 \mathrm{ng} \mathrm{ml}^{-1} ; P>0.05\right)$. Nevertheless, at day 30 postpartum, LH pulse frequency was lower in LE cows with a high plasma NEFA concentration $(0.60 \pm 0.24$ pulses per $10 \mathrm{~h}$, when NEFA concentrations were higher than $300 \mu \mathrm{eq} \mathrm{I}^{-1}$ ) than in LE cows presenting a low plasma NEFA concentration $(3.00 \pm 1.00$ pulses per $10 \mathrm{~h}$, when NEFA concentrations were lower than $300 \mu \mathrm{eq} 1^{-1} ; P<0.05$ ) and than in $C E$ cows $(2.00 \pm 0.25$ pulses per $10 \mathrm{~h}$, plasma NEFA concentration $<300$ ueq $\mathrm{l}^{-\mathrm{I}} ; P<0.05$ ).

In addition, the number of $\mathrm{LH}$ peaks per $10 \mathrm{~h}$ was negatively correlated with plasma NEFA concentrations during period 1 $(r=-0.61 ; P<0.01 ; n=17)$ but not period $2(r=0.16$; $P=0.51 ; n=18$ ).

Oestradiol. Energy supply had no significant effect on mean plasma oestradiol concentrations (CE: $4.07 \pm 0.24 \mathrm{pg} \mathrm{ml}^{-1}$; LE: $4.48 \pm 0.24 \mathrm{pg} \mathrm{ml}^{-1} ; P>0.05$ ). Neither parity nor time postpartum affected mean plasma oestradiol concentrations, but individual values observed during the two periods were significantly correlated $(r=0.7 ; P<0.01)$.

Plasma concentrations of oestradiol were negatively correlated with glycaemia $(r=-0.33, P<0.05, n=35)$ and with insulinaemia $(r=-0.35, P<0.05, n=35)$ when the two periods were pooled. 
(a)
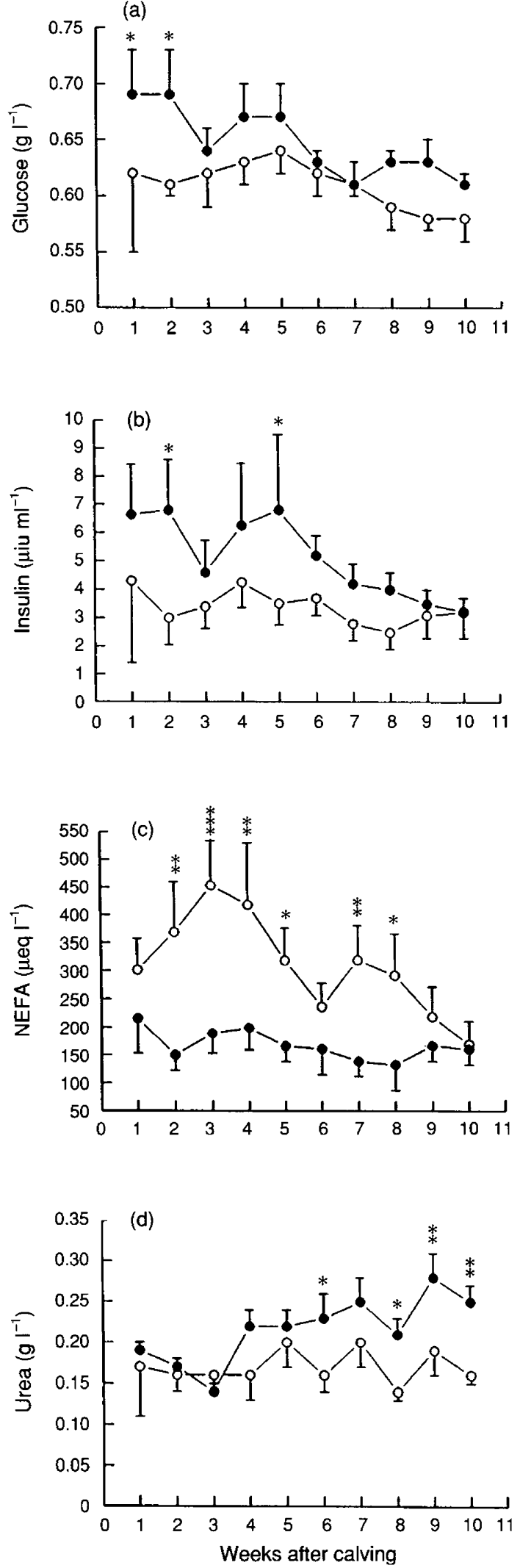

Fig. 1. Evolution of plasma concentrations of (a) glucose, (b) insulin, (c) non-esterified fatty acids (NEFA) and (d) urea concentrations in postpartum suckled beef cows fed $100 \%(\bullet, n=10)$ or $70 \%(0, n=9)$ of energy requirements. ${ }^{*} P<0.05,{ }^{*} P<0.01,{ }^{* * *} P<0.001$.
Table 1. Effect of period of observation on follicular characteristics in postpartum beef cows fed 100\% (control energy; CE) or $70 \%$ (low energy; LE) of energy requirements

\begin{tabular}{lllll}
\hline & & \multicolumn{3}{c}{ Ovarian status } \\
\cline { 3 - 5 } Period & Diet & $\begin{array}{c}\text { No large } \\
\text { follicle }\end{array}$ & $\begin{array}{c}\text { Multiple large } \\
\text { follicles }\end{array}$ & $\begin{array}{c}\text { Single large } \\
\text { follicle }\end{array}$ \\
\hline \multirow{2}{*}{$20-30$ days } & CE & $2 / 10$ & $6 / 10$ & $2 / 10$ \\
& LE & $3 / 9$ & $3 / 9$ & $3 / 9$ \\
& Total & $5 / 19$ & $9 / 19$ & $5 / 19$ \\
$40-50$ days & CE & $0 / 10$ & $4 / 10$ & $6 / 10$ \\
& LE & $4 / 9$ & $2 / 9$ & $3 / 9$ \\
& Total & $4 / 19$ & $6 / 19$ & $9 / 19$ \\
& & & &
\end{tabular}

${ }^{\mathrm{a}}$ Diameter $\geq 10 \mathrm{~mm}$.

${ }^{b}$ Growing simultaneously.

Progesterone. Only three multiparous cows ovulated between day 50 and day 70 postpartum, one in the restricted group (maximum progesterone concentration: $1.56 \mathrm{ng} \mathrm{ml}^{-1}$ ) and two in the control group (maximum progesterone concentrations: 1.8 and $3.5 \mathrm{ng} \mathrm{ml}^{-1}$, respectively). No primiparous cow ovulated before day 70 postpartum.

\section{Follicular characteristics}

Between day 40 and day 50 postpartum (period 2), cows had more small (period 2: $3.49 \pm 0.14$; period 1: $2.52 \pm 0.10$; $P<0.01$ ) and medium sized follicles (period 2: $4.93 \pm 0.11$; period 1: $4.24 \pm 0.11 ; P<0.01)$ than between day 20 and day 30 postpartum (period 1). Time postpartum did not affect the number of large follicles but the size of the largest follicle increased slightly between period 1 and period $2(9.2 \pm 0.1 \mathrm{~mm}$ versus $9.6 \pm 0.2 \mathrm{~mm} ; P<0.05$ ).

During period 1 , five cows had no large follicles (Table 1 ) and 14 of 19 cows presented one or more large growing follicles. Among those, only five cows could be considered as carrying a dominant follicle. The proportion of cows in the various ovarian states was not significantly different during period 2, when compared with period 1. Nevertheless, the number of cows expressing a single dominant follicle tended to increase between period 1 and period 2 in CE cows ( 2 of 10 versus 6 of 10), whereas it remained the same in LE wws ( 3 of 9).

Primiparous cows had fewer medium sized and small follicles than did multiparous cows (primiparous: $3.66 \pm 0.11$; multiparous: $5.52 \pm 0.11$, for medium sized follicles, $P<0.01$; primiparous: $2.58 \pm 0.09$; multiparous: $3.43 \pm 0.10$, for small sized follicles, $P<0.05)$. However, there was no effect of parity on the number or size of large follicles.

The number of small and medium sized follicles and the size of the largest follicle increased more with time postpartum in multiparous cows than in primiparous ones (interaction parity $\times$ time postpartum significant; $P<0.01 ; P<0.01$ and $P=0.07$, respectively, for these variables).

The effect of energy supply on the number of medium sized and small follicles was not significant (CE: $4.37 \pm 0.11$; LE: 


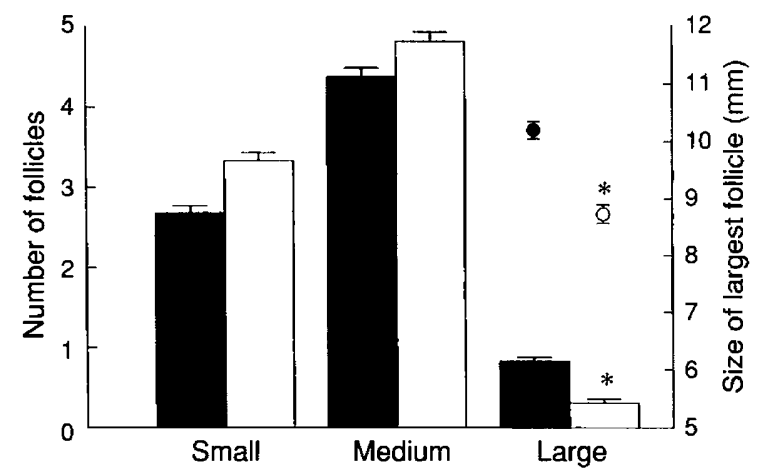

Fig. 2. Mean number of small (diameter $<5 \mathrm{~mm}$ ), medium ( $5 \leq$ diameter $<10 \mathrm{~mm}$ ) and large (diameter $\geq 10 \mathrm{~mm}$ ) follicles, and size of the largest follicle (mm, in circles) observed $20-30$ and $40-50$ days postpartum in beef suckled cows fed $100 \%(\boldsymbol{\square}, \bullet)$ or $70 \%$ $(\square, 0)$ of energy requirements. ${ }^{*} P<0.05$.

$4.81 \pm 0.11$ for medium sized follicles, $P>0.05$; $C E$ : $2.68 \pm 0.09$; LE: $3.33 \pm 0.10$ for small sized follicles, $P>0.05$; Fig. 2). Control cows had more large sized follicles than LE females $(0.82 \pm 0.05$ versus $0.31 \pm 0.05 ; P<0.05)$. The size of the largest follicle was higher in $\mathrm{CE}$ cows than in LE cows (10.2 $\pm 0.1 \mathrm{~mm}$ versus $8.7 \pm 0.2 \mathrm{~mm} ; P<0.05$ ).

The number of small follicles was negatively correlated with plasma concentration of insulin during period $1(r=-0.48$; $P<0.05 ; n=19$ ). At the same time, the number of medium sized follicles was negatively correlated to plasma concentration of glucose $(r=-0.49 ; \quad P<0.05 ; n=19)$. These correlations were not significant for period 2. However, the size of the largest follicle was negatively correlated with NEFA concentration during the second period $(r=-0.5 ; P<0.05$; $n=19)$.

\section{Discussion}

As reported by Russel and Wright (1983) and Easdon et al. (1985), plasma concentrations of glucose, insulin and NEFA appear to be pertinent criteria to estimate the energy status of postpartum beef cows. The level of undernutrition used in this study reduced the availability of glucose (by producing lower plasma glucose and insulin concentrations) without inducing hypoglycaemia, but increased body reserve mobilization (by producing higher NEFA concentrations) in LE cows. These cows did not use their protein body reserves to generate glucose, as urea concentrations remained low.

The mobilization of body energy reserves decreased with time postpartum in underfed suckled beef cows as described by Easdon et al. (1985): LE cows lost weight and milk production was lower and this resulted in lower maintenance and production requirements. At day 70 postpartum, LE cows, despite their lower body reserves, had the same metabolic energy. status as adequately fed, $C E$, females (there were no differences between groups in plasma concentrations of glucose, insulin or NEFA). This evolution of energy status with time may explain some contradictions reported in previous studies investigating the relationship between nutrition and reproduction. In situations with a strong negative energy balance, energy supply has a negative effect on reproduction but, because cows fed low energy diets appear to re-equilibrate their energy balance with time postpartum, this effect may disappear. Moreover, when the extent of body reserves is equal at calving, the time postpartum necessary to recover an energy status compatible with normal reproductive function may increase with undernutrition. This time taken to re-equilibrate energy balance could also be affected by the extent of tissue reserves and the efficiency with which these reserves can be mobilized.

The well-established effects of time postpartum on $\mathrm{LH}$ secretion and follicular growth were confirmed in this study. With increasing time postpartum, the LH pulse frequency increased as described by Nett (1987). Recruitment and growth of ovarian follicles increased with time postpartum as reported by Spicer et al. (1986) and Murphy et al. (1990). Large follicles were present in the ovaries, whereas no ovulation occurred as observed by Murphy et al. (1990), who noted 3.2 (range 1-6) waves of growth and atresia of large follicles before the first ovulation in adequately fed postpartum beef cows. Nevertheless, in this experiment, follicular waves could not be clearly identified in most cows, which presented either no large follicles or several large follicles growing simultaneously in the same ovary.

In this study, parity had an effect on reproductive efficiency. LH secretion was lower and the process of recruitment was less effective in primiparous cows than in multiparous females. These observations may be related to the longer interval from calving to first ovulation observed in primiparous cows (Petit et al., 1977; Aguer et al., 1981; Grimard and Mialot, 1990; Short et al., 1990; Agabriel et al., 1992; Grimard et al., 1992). In addition, in primiparous cows, glucose and insulin concentrations were reduced by energy restriction, whereas they were unchanged in multiparous cows; thus, the influence of energy level of the diet on metabolic status was more important in primiparous cows. This finding may explain the greater influence of nutrition on reproduction in young animals reported by Agabriel et al. (1992), Grimard et al. (1992), Kabandana et al. (1993), and Petit and Agabriel (1993).

In the study reported here, energy supply did not influence LH secretion characteristics. These results seem to be in contradiction with the observations of Terqui et al. (1982), Gauthier and Mauleon (1983), Whisnant et al. (1985), and Wright et al. (1992), but these authors used a higher level of restriction or measured $\mathrm{LH}$ secretion sooner after calving. Moreover, in this study, LH pulse frequency was found to be negatively correlated with NEFA concentrations at day 30 postpartum (i.e., at a time when mobilization of body reserves is high). This correlation was not significant at a later stage, when NEFA concentrations were lower. It can be hypothesized that the effect of nutrition on $\mathrm{LH}$ secretion is particularly pronounced when energy balance is strongly negative (e.g., when there is energy restriction in thin cows at calving (Wright et al. 1992) or shortly after calving). This effect is no longer observed when cows have re-equilibrated their energy balance (e.g., when there is energy restriction in fat cows at calving or a long time after calving).

The greater number of large follicles observed in CE cows when compared with LE cows suggests that physiological mechanisms responsible for ovarian follicular growth and dominance may become functional at an earlier stage in 
adequately fed females compared with underfed ones. This is in agreement with the data of Lucy et al. (1989), Prado et al. (1990), and Perry et al. (1991). The effect of nutrition on follicular growth was not found to be related to LH secretion in the study reported here. In addition, the greater number of large follicles was not associated with a parallel increase in steroidogenic capacity: plasma oestradiol concentrations were low and unaffected by energy supply, as reported by Lishman et al. (1979) and Murphy et al. (1990) in beef cattle. This finding suggests that different mechanisms control the effect of nutrition on the process of selection of large follicles and the process of oestradiol secretion. Plasma oestradiol concentrations were negatively correlated in this study with plasma glucose and insulin concentrations. This result is in agreement with the observations of Downing et al. (1993) in sheep ovaries in vivo and of Veldhuis et al. (1983) in cultured porcine granulosa cells in vitro.

In conclusion, these results show that individual patterns of blood metabolites (and particularly NEFA) have to be taken into account when studying the effect of undernutrition on reproduction. Variations in individual responses to undernutrition may explain some of the conflicting results observed in the literature. In this study, LH profiles were affected at day 30 postpartum in underfed cows expressing a strong negative energy balance but not in those that had re-equilibrated their energy balance. Differences between underfed and control cows until day 50 postpartum were more striking in terms of follicular growth. Finally, primiparous cows appeared much more sensitive to undernutrition than did multiparous cows and this should be taken into account when investigating relationships between nutrition and reproductive events.

The authors thank Y. Durand (Chambre d'Agriculture de Saône et Loire); P. Bas and F. Ternois (Station de Nutrition, INAPG, Paris); N. Jeanguyot and $S$. Germain (Laboratoire de dosages hormonaux de I'Unceia); V. Parez (Laboratoire Intervet); M. Sanaa (Laboratoire d'Epidémiologie et de Gestion de la Santé Animale de L'Enva) for advice on statistical analysis; N. Novak, F. Kabandana, B. Khireddine and $\mathrm{O}$. Ribon for care of the animals.

\section{References}

Agabriel J, Giraud JM and Petit M (1986) Détermination et utilisation de la note d'état d'engraissement en élevage allaitant Bulletin Technique du CRZV de Theix 66 43-50

Agabriel J, Grenet N and Petit M (1992) Etat corporel et intervalle entre vêlages chez la vache allaitante: bilan de deux années d'enquête en exploitation INRA Productions Animales 5 355-369

Aguer D, Pelot J and Chupin D (1981) Reproduction du troupeau à viande et synchronisation de l'oestrus Bulletin Technique des GTV 1 33-57

Barnouin J, El Idilbi N, Chilliard Y, Chacornac JP and Lefaivre R (1986) Microdosage automatisé sans déprotéinisation du $\beta$-hydroxy-butyrate plasmatique chez les bovins Annales de Recherche Vétérinaire 17 129-139

Boly H, Humblot P, Tillet $Y$ and Thibier M (1994) Effects of Trypanosoma congolense infection on the pituitary gland of Baoulé bulls: immunohistochemistry of LH- and FSH-secreting cells and response of plasma $\mathrm{LH}$ and testosterone to combined dexamethasone and GnRH treatment Journal of Reproduction and Fertility 100 157-162

Downing JA, Scaramuzzi RJ and Joss J (1993) The direct effect of insulin on ovarian steroid secretion in ewes with an autotransplanted ovary Proceedings of the Australian Society for Reproductive Biology 2554 (Abstract)

Easdon MP, Chesworth JM, Aboul-Ela MBE and Henderson GD (1985) The effect of undernutrition of beef cows on blood hormone and metabolite concentrations post partum Reproduction Nutrition Development 25 113-126
Gauthier D and Mauleon P (1983) Influence of dietary intake and weight variation on $\mathrm{LH}$ after gonadotropin-releasing hormone $(\mathrm{GnRH})$ injection during the post-partum period of the nursing cow Reproduction Nutrition Development 23 829-835

Grimard B and Mialot JP (1990) Avancer et regrouper les vêlage grâce à la maîtrise des cycles sexuels dans les systèmes allaitants traditionnels Elevage et Insémination 240 15-30

Grimard B, Humblot P, Parez V, Mialot JP and Thibier M (1992) Synchronisation de l'oestrus chez la vache Charolaise: facteurs de variation de la cyclicité prétraitement, du taux d'ovulation après traitement et du taux de fertilité à l'oestrus induit Elevage et Insémination 250 5-17

Humblot P, de Montigny G, Jeanguyot N, Tefedoie F, Payen B, Thibier M and Sasser RG (1990) Pregnancy specific protein B and progesterone concentrations in French Alpine goats throughout gestation Journal of Reproduction and Fertility 89 205-212

Kabandana F, Grimard B, Humblot $\mathbf{P}$ and Thibier $\mathbf{M}$ (1993) Effet d'une supplémentation alimentaire sur l'efficacité des traitements de d'induction et de synchronisation de l'oestrus chez la vache allaitante: références particulières aux primipares non cyclées Elevage et Insémination 258 1-14

Lishman AW, Allison SMJ, Fogwell RL, Butcher RL and Inskeep EK (1979) Follicular development and function of induced corpora lutea in underfed postpartum anoestrus beef cows Journal of Animal Science 48 867-875

Lucy MC, Staples CR, Tatcher WW, Lough DS, Michel FJ and Beede DK (1989) Influence of energy balance of dairy cattle from 0 to 42 days postpartum on ovarian follicular populations Journal of Animal Science 67 (Supplement 1) 386 (Abstract)

Maurel MC (1991) Development of an ELISA kit for the determination of LH in the farm. In Proceedings of the 7th meeting of the Association Europeenne de Transfert Embryonnaire Cambridge p 176. Fondation Merieux, Lyon

Murphy MG, Boland MP and Roche JF (1990) Pattern of follicular growth and resumption of ovarian activity in post-partum beef suckler cows journal of Reproduction and Fertility $90523-533$

Nett TM (1987) Function of the hypothalamic-hypophysial axis during the post-partum period in ewes and cows Journal of Reproduction and Fertility 34 201-213

Perry RC, Corah LR, Cochran RC, Beal WE, Stevenson JS, Minton JE, Simms DD and Brethour JR (1991) Influence of dietary energy on follicular development, serum gonadotropins, and first postpartum ovulation in suckled beef cows joumal of Animal Science $693762-3773$

Petit M (1988) Alimentation des vaches allaitantes. In Alimentation des Bovins, Ovins et Caprins pp 159-184. INRA, Paris

Petit M and Agabriel J (1993) Etat corporel des vaches allaitantes Charolaises: signification, utilisation pratique et relations avec la reproduction INRA Productions Animales 6 311-318

Petit M, Chupin D and Pelot J (1977) Analyse de l'activité ovarienne des femelles bovines. In Physiopathologie de la Reproduction, Journées ITEBUNCEIA 21-28. ITEB, Paris

Pierson RA and Ginther OJ (1984) Ultrasonography of the bovine ovary Theriogenology 21 495-504

Prado R, Rhind SM, Wright IA, Russel AJF, McMillen SR, Smith AJ and McNeilly AS (1990) Ovarian follicle population, steroidogenicity and micromorphology at 5 and 9 weeks post partum in beef cows in two levels of body condition Animal Production 51 103-108

Randel RD (1990) Nutrition and postpartum rebreeding in cattle Journal of Animal Science 68 853-862

Russel AJF and Wright IA (1983) The use of blood metabolites in the determination of energy status in beef cows Animal Production 37 335-343

Rutter LM and Randel RD (1984) Postpartum nutrient intake and body condition: effect on pituitary function and onset of oestrus in beef cattle Journal of Animal Science 58 265-274

SAS (1987) STAT user's guide. SAS Institute Inc., Cary, NC

Savio JD, Boland MP, Hynes N and Roche JF (1990) Resumption of follicular activity in the early post-partum period of dairy cow Journal of Reproduction and Fertility 88 569-579

Short RE, Bellows RA, Staigmiller RB, Berardinelli JG and Custer EE (1990) Physiological mechanisms controlling anestrus and infertility in postpartum beef cattle Journal of Animal Science 68 799-816

Spicer LJ, Leung K, Convey EM, Gunther J, Short RE and Tucker HA (1986) Anovulation in postpartum suckled beef cows. I: Association among size and numbers of ovarian follicles, uterine involution, and hormones in serum and in follicular fluid Journal of Animal Science 62 734-741 
Terqui M, Chupin D, Gauthier D, Perez N, Pelot J and Mauleon P (1982) Influence of management and nutrition on post partum endocrine function and ovarian activity in cows. In Current Topics in Veterinary Medicine and Animal Science. Factors Influencing Fertility in the Post Partum Cows pp 384-408. Martinus Nijhoff, The Hague

Thibier $\mathbf{M}$ and Saumande $\mathbf{J}$ (1975) Oestradiol $17 \beta$, progesterone and $17 \boldsymbol{\alpha}$ hydroxyprogesterone concentrations in jugular venous plasma in cows prior to and during oestrus Journal of Steroid Biochemistry 6 1433-1437

Veldhuis JD, Kolp LA, Toaff ME, Strauss JF and Demers LM (1983) Mechanisms subserving the trophic actions of insulin on ovarian cells: in vitro studies using swine granulosa cells Journal of Clinical Investigations 72 1046-1054
Whisnant CS, Kiser TE, Thompson FN and Hall JB (1985) Effect of nutrition on the $\mathrm{LH}$ response to calf removal and GnRH Theriogenology 24 565-573

Wright IA, Rhind SM, Russel AJF, Whyte TK, McBean AJ and McMillen SR (1987) Effects of body condition, food intake and temporary calf separation on the duration of the post partum anoestrus period and associated $\mathrm{LH}$, FSH and prolactin concentrations in beef cows Animal Production 45 395-402

Wright IA, Rhind SM, Whyte TK and Smith AJ (1992) Effects of body condition at calving and feeding level after calving on LH profiles and the duration of the postpartum anoestrus period in beef cows Animal Production 55 $41-46$ 